\title{
Cover crop adoption in lowa: The role of perceived practice characteristics
}

\author{
J.G. Arbuckle Jr. and G. Roesch-McNally
}

\begin{abstract}
Cover crops are widely viewed by the soil and water conservation community to be an effective means for reducing soil erosion and nutrient loss and increasing soil health, yet relatively few farmers have adopted the practice. Despite the widespread recognition of cover crops' benefits and increased promotional efforts, there have been very few peer-reviewed studies focused on farmer perspectives on or adoption of cover crops. This study, which analyzed data from a survey and in-depth interviews with Iowa farmers, examined the roles that perceived practice characteristics, perspectives on potential facilitating factors, and crop and livestock diversity play in cover crop adoption among Iowa farmers. As expected, perceived benefits were strongly associated with cover crop use. Measures of crop and livestock diversity were also positive predictors of adoption. In addition, farmers who endorsed strengthening of facilitating factors such as educational and technological infrastructure to support cover crop use were more likely to have adopted cover crops. Farmers who perceived higher levels of risks associated with cover crop use, on the other hand, were less likely to use them. Results suggest that research and promotional efforts should focus on both raising awareness of potential benefits and quantifying and communicating potential risks and risk abatement strategies. Helping farmers to better understand (1) the benefits of cover crops and how they can be enhanced, and (2) the potential risks and ways that they can be minimized might allow farmers to more effectively weigh the probable benefits and costs of cover crop use. The findings further suggest that farmers believe that better facilitating infrastructure, in the form of technical assistance (e.g., agricultural retailers and custom operators) and education, is needed to support the widespread adoption of cover crops.
\end{abstract}

Key words: adoption—cover crops—qualitative research—soil health—water quality

Cover crops are widely viewed by the soil and water conservation community to be an effective means for reducing soil erosion and nutrient loss and increasing soil health, yet relatively few farmers have adopted the practice. Cover crops are defined as "crops grown primarily for the purpose of protecting and improving soil between periods of regular crop production" (Schnepf and Cox 2006). Cover crops have long been valued for their soil conservation benefits, including reducing erosion, increasing infiltration, and improving soil health (Chatterjee 2013; Kaspar et al. 2001; Kaspar and Singer 2011; Schnepf and Cox 2006). More recently, as agriculture's impact on water quality has become a national concern (CENR 2010; Ribaudo 2011), the potential water quality benefits of cover crops, such as decreasing nitrate $\left(\mathrm{NO}_{3}\right)$ leaching into sur- have resilience-enhancing properties that are important for adaptation as well as the potential to reduce greenhouse gas emissions through carbon (C) sequestration and nitrogen $(\mathrm{N})$ use efficiencies, although to date findings on greenhouse gas reduction have been mixed (Basche et al. 2014; Lal et al. 2011).

Despite ample evidence of the benefits of cover crops, and increased effort to promote their use, adoption of cover crops is low across the Midwest. The 2012 Census of Agriculture estimated that about 3\% of US cropland was planted to cover crops in 2011 (USDA NASS 2014). For Iowa, the estimate was less than $2 \%$ of cropland acres in cover crops (USDA NASS 2014). Singer et al. (2007) found that in 2006, only $11 \%$ of farmers surveyed in Illinois, Iowa, Minnesota, and Indiana had grown a cover crop within the previous five years. Further, an analysis of seed dealer data in 2011 calculated that less than $2 \%$ of total cropland acreage in the Mississippi River Basin was planted in cover crops (Bryant et al. 2013).

Given the mounting scientific evidence of the benefits of cover crops, the recent emphasis on cover crop promotion among conservation agencies and organizations, and the relative lack of cover crop adoption by farmers, surprisingly little research has focused on farmer adoption of cover crops. An extensive literature review revealed only one peer-reviewed quantitative study that focused solely on cover crop adoption (Singer et al. 2007); one peer-reviewed qualitative study, which focused on adoption of cover crops among several other practices (Reimer et al. 2012); and several technical reports (Arbuckle and Ferrell 2012; CTIC 2013, 2014). Carlson and Stockwell (2013) note this dearth of research and cite an urgent need for a better understanding the factors associated with cover crop adoption.

The objective of this research is to evaluate factors that influence the adoption of cover crops in Iowa. In particular, it examines the relationships between farmers' perceptions of cover crops - benefits, risks, and facilitating factors - and their use of cover crops. The study

J. Gordon Arbuckle Jr. is associate professor of sociology and extension sociologist and Gabrielle Roesch-McNally is a PhD candidate in the Department of Sociology, lowa State University, Ames, lowa. 
draws on quantitative data from a survey of 1,128 Iowa farmers and qualitative data from in-depth interviews with 20 Iowa farmers.

\section{Materials and Methods}

Conceptual Framework. This research on cover crop adoption draws on two major traditions in the assessment of behavioral change: diffusion of innovations (Fliegel 1993; Rogers 2003), and the reasoned action approach (RAA) (Ajzen 1991; Fishbein and Ajzen 2010), which are two frameworks commonly employed in research that explores the adoption of agricultural best management practices. Specifically, we adapt Reimer et al.'s (2012) innovative combination of components of the two traditions to frame the study. Reimer et al. (2012) proposed that insight into agricultural decision-making processes could be improved by integrating "perceived practice characteristics," or the qualities that prospective users of a practice compare to their current practices as they consider a potential change in behavior (Rogers 2003), into the RAA model. This research employs that combined approach.

The analysis was guided by an adaptation of Reimer et al.'s (2012) framework (figure 1). The right side of figure 1 outlines the conceptual core of the RAA. The RAA posits that adoption of a behavior is influenced by three distinct types of beliefs, which are closely related to perceptions of the actual behavior (Fishbein and Ajzen 2010). Behavioral beliefs, or beliefs about potential consequences of a given behavior, influence positive or negative attitudes toward the behavior. Normative beliefs, or beliefs about the social acceptability of the behavior, lead to perceptions of social norms related to engaging in the behavior or not. Control beliefs, or beliefs about what is generally possible, shape individuals' perceived capacity to perform a behavior (self-efficacy), which is distinct from actual control (i.e., having the resources and opportunities needed to act) (Ajzen 1991). Together, those belief-perception pairs influence intentions to undertake the behavior, which can lead to actual behavior change.

The second major component of the RAA is labeled "background factors" (Fishbein and Ajzen 2010). This is a catch-all category for potential determinants of beliefs and attitudes/perceptions. Since any given behavior can have its own constellation of influential contextual factors, inclusion of variables in this category should be guided by theory relevant to a given behavior and context. The specific relationships between contextual variables and behaviors thus become empirical questions that can lead to better understanding of the determinants of a particular behavior (Fishbein and Ajzen 2010). In the case of conservation practice adoption, major categories of contextual variables include personal characteristics (e.g., demographics, general attitudes, and knowledge and awareness), farm characteristics (e.g., crop/livestock mix and farm size), and external context (e.g. information networks, market conditions, and government policies) (Baumgart-Getz et al. 2012; Knowler and Bradshaw 2007; Prokopy et al. 2008; Rogers 2003).

Reimer et al. (2012) introduced perceived practice characteristics to the RAA Drawing on the diffusion of innovations research tradition (Rogers 2003), which posits that farmers' perceptions regarding how new practices compare to current practices are major determinants of adoption, Reimer et al. (2012) integrated perceived practice characteristics into the RAA model as critical mediators between contextual factors and beliefs-perceptions about conservation practice adoption. Rogers (2003) listed five categories of perceived practice characteristics that have been applied to research on adoption of agricultural innovations:

1. Relative advantage, or evaluation of whether an innovation is an improvement over current practice. Advantage can be considered both objectively and subjectively in terms of economics, prestige, satisfaction, or other dimensions.

2. Complexity, or perceptions of how difficult an innovation might be to implement

3. Compatibility, or comparative fit with values, experience, or perceived needs.

4. Trialability, or the degree to which an innovation can be tried on a limited scale before broader adoption.

5. Observability, or the ease with which results can be viewed by the adopter or others.

Reimer et al. (2012) also introduced a critical sixth category: risk. Risk, or the possibility of loss or harm, is endemic to agriculture due to uncertainties in weather, pests, etc., and most farmers are risk-averse (Harwood et al. 1999). The introduction of risk is important because evaluation of risk is central to decisions about conservation practices, especially those that might negatively impact yields (Harwood et al. 1999).
Incorporation of perceived practice characteristics into the RAA model improves the framework's usefulness for evaluation of conservation practice adoption, because the degree to which a given practice aligns with current systems will likely influence farmers' behavioral, normative, and control beliefs, their concomitant attitudes and perceptions about the practice, and, ultimately, their willingness to adopt the practice.

Accordingly, this research centers on the influence of perceived practice characteristics and elements of belief structures on farmer adoption of cover crops. Guided by the conceptual framework, this research evaluates the relationships between selected practice characteristics, beliefs and attitudes, contextual factors, and the adoption of cover crops by Iowa farmers.

Data. This study draws on both quantitative survey data and qualitative data from in-depth interviews. The survey and in-depth interview data were collected through separate but connected research efforts focused on Iowa farmers' perspectives on cover crops. The survey data employed in this study are from the 2014 Iowa Farm and Rural Life Poll (IFRLP) survey and the interview data were collected in Iowa as part of the USDA-funded Corn-based Cropping Systems Coordinated Agricultural Project (Morton 2014). Because the data were collected for different projects, the study is not technically a "mixed method" study. Nevertheless, we analyze the quantitative and qualitative data from both projects because the two types of data can complement each other as the strengths of each method can compensate for the potential weaknesses of the other (Small 2011).

The IFRLP is an annual mail survey of Iowa farmers that is conducted by Iowa State University Extension in partnership with the USDA National Agricultural Statistics Service and the Iowa Department of Agriculture and Land Stewardship. The survey was mailed in February of 2014 to 2,218 farmers and completed by 1,128 for a response rate of $51 \%$. Only farmers who reported that they produced crops and/or livestock in 2013, who made up $92 \%$ of the overall sample $(n=960)$ were included in the analysis. The remaining $8 \%$ had some other kind of agricultural enterprise, had recently retired, or only had land enrolled in the Conservation Reserve Program.

The IFRLP is a longitudinal panel survey that began as a random sample survey 


\section{Figure 1}

Conceptual framework, adapted from Reimer et al. (2012).

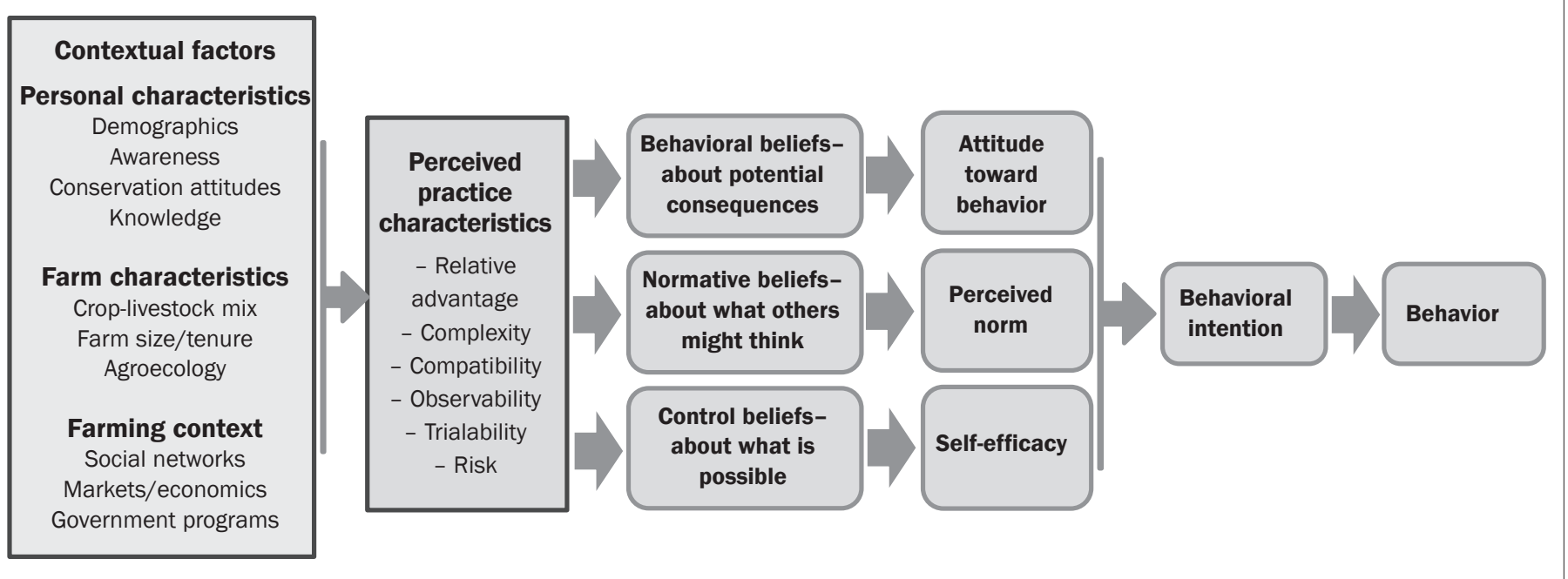

and has been administered annually since 1982. Because it is a long-running panel survey, over time the number of farmers in the sample declines due to retirement and other factors. To address this attrition, the survey panel is periodically replenished with a random sample selected from the Census of Agriculture master list. Compared to the Census of Agriculture, the IFRLP sample is biased toward larger-scale farmers. The Census of Agriculture master list contains numerous people who do not farm, but are defined as farmers by the USDA because they could potentially produce US $\$ 1,000$ in sales annually. When such people are drawn in the IFRLP periodic random samples, they generally choose not to participate because most questions are not relevant to them.

A comparison of 2014 IFRLP respondents to selected 2012 Census of Agriculture statistics for Iowa documents the bias toward larger-scale farmers. The farmers in the IFRLP sample operated an average of $187 \mathrm{ha}$ (462 ac), compared to 140 ha (346 ac) among the 2012 census population (table 1). Comparison of farm sales shows that $28 \%$ of farmers in the 2012 census population had gross farm sales of less than US $\$ 2,500$, compared to just $5 \%$ of IFRLP farmers. At the other end of the sales spectrum, $41 \%$ of the census population reported sales greater than US $\$ 100,000$, compared to $56 \%$ of IFRLP farmers. While this bias toward larger-scale farmers might be seen as a liability for some research efforts, for this study it is considered an asset because larger-scale farms operate a disproportionate amount of acreage that would be appropriate for cover crops: the minority of Iowa farms that generate US $\$ 100,000$ or more in gross sales operate $90 \%$ of the cropland acres (USDA NASS 2014).

The qualitative data were drawn from in-depth, semistructured interviews that were conducted as part of a larger project for which 159 farmers across nine Corn Belt states were interviewed to learn about their conservation practice decision making. Given the Iowa focus of the survey data, only the subset of interviews from Iowa farmers $(n=20)$ were analyzed as part of this study. The farmers who were interviewed generally had larger-scale (162 ha [400 ac] or more) operations with a substantial row crop component, primarily consisting of a corn (Zea mays L.) and soybean (Glycine max [L.] Merr.) rotation. Farmers who were connected to Iowa State University Extension networks (i.e., who attend extension events and/or were in frequent contact with extension educators) were purposively recruited. Due to this selection method, interview participants were likely more conservationminded than the broader population of farmers in the state, and a number of them had used cover crops recently. This probable bias toward conservation-minded farmers was seen as an asset because farmers who have tried numerous conservation practices can be particularly qualified to explain associated challenges and how to overcome them (or not).

A primary objective of the interviews was to develop a better understanding of farmers' perspectives on conservation practice use (or non-use). The interview protocol focused on three major types of conservation practices: nutrient management practices, tillage practices, and cover crops. This analysis centers primarily on the cover crops questions. Farmers who were currently using cover crops were asked to share their views on motivations underlying their decision to adopt, the primary benefits of cover crop use, any challenges that they may have encountered, and the information sources that they use to learn about cover crops. Farmers who were not using cover crops were asked to explain why they did not use them, with a particular focus on perceived barriers and risks.

The interview data were analyzed by employing a hierarchical axial coding procedure to identify emergent themes related to cover crops (Corbin and Strauss 1990). A number of themes associated with cover crop use were identified based on the interview protocol and preliminary analysis of the interview data. Following identification of key themes associated with this study's research questions (e.g., perceived benefits and perceived risks related to cover crops), a coding framework was developed to guide the coding procedure, which was iteratively modified based on discussion and preliminary coding (Hruschka et al. 2004). To enhance the reliability of the analysis, two coders independently analyzed the interview transcripts and coded responses into a number of main themes, with relevant subthemes based on the coding framework (Hruschka et al. 2004; Prokopy 2011). High levels of agreement were achieved between the two analyses. Finally, to improve the validity and transparency of the analysis, direct quotes 


\section{Table 1}

Comparison of farm characteristics: study sample (from lowa Farm and Rural Life Poll [IFRLP]) and 2012 Census of Agriculture (IFRLP 2014; USDA NASS 2014).

\begin{tabular}{lcc}
\hline Characteristic & IFRLP sample & Ag census \\
\hline Average farm size (ha) & 187 & 140 \\
Farms with sales less than US $\$ 2,500$ (\%) & $5.1 \%$ & $28.2 \%$ \\
US $\$ 2,501$ to US $\$ 9,999$ & $5.7 \%$ & $9.0 \%$ \\
US $\$ 10,000$ to US $\$ 99,999$ & $33.3 \%$ & $21.7 \%$ \\
US $\$ 100,000$ to US $\$ 249,999$ & $22.8 \%$ & $11.3 \%$ \\
US $\$ 250,000$ to US $\$ 499,999$ & $18.0 \%$ & $11.0 \%$ \\
US $\$ 500,000$ to US $\$ 999,999$ & $9.9 \%$ & $10.9 \%$ \\
US\$1 million or more & $5.2 \%$ & $7.8 \%$
\end{tabular}

have been included in the results section to allow readers to better grasp the context and meanings associated with these interview data (Prokopy 2011). Not all themes identified as part of this coding procedure are examined in this paper as there were additional findings that are beyond the scope of this effort and will be a part of future analyses.

Data analysis was conducted in two stages. The first stage employed logistic regression to model relationships between 12 covariates and a binary measure of cover crop use. The second stage examined emergent themes from the in-depth interview data and incorporated relevant analysis and quotes into the discussion of model results. The objective of this complementary approach is to provide more robust and nuanced interpretations of the results of the statistical analysis and a better understanding of the adoption process overall.

Variables in the Model. The survey provided a short definition of cover crops ("cover crops are plants that are purposefully planted to cover the soil between the harvest and planting of cash crops, typically from fall until spring") and asked farmers to respond to a series of cover crops-related questions. The first question determined whether or not respondents had planted cover crops in 2013. The dependent variable is a binary measure of cover crop use (yes $=1$, no $=0$ ).

Twelve independent variables measuring key components of the conceptual framework are included in the statistical analyses. Four of the independent variables are summated rating scales. The scales were constructed by summing responses on multiple survey items that elicited a response on a five-point scale ranging from strongly disagree (1) to strongly agree (5), then dividing the sum by the number of items to facilitate comparability between scales. Summated rating scales are often preferred to multiple single-item scales for attitude measurement because attitudinal constructs are complex and multidimensional (DeVellis 2003; McIver and Carmines 1981; Spector 1992). Summated scales that combine multiple single-item scales to measure attitudinal constructs can improve both reliability and precision of measurement, while simultaneously addressing collinearity between closely related items that measure latent constructs (Field 2009). The means and percentage distributions for the individual items that compose the scales are provided along with the descriptive statistics for the scales themselves in the results section (tables 2 and 3 ). To evaluate the internal consistency of the scales, we calculated Cronbach's alpha reliability coefficients, a common measure of scale reliability (Field 2009), for each scale.

The primary variables of interest are three scales measuring varied aspects of farmer perceptions of the practice characteristics outlined in the conceptual framework: relative advantage, complexity, compatibility, observability, trialability, and risk. They also measure dimensions of the behavioral, normative, and control beliefs that influence attitudes, perceived norms, and self-efficacy as they all relate to cover crops. The three scales are labeled "perceived benefits" of cover crops, "perceived risks" associated with cover crops, and "potential facilitators" of cover crop use.

The perceived benefits scale is composed of three items: (1) cover crops can reduce $\mathrm{N}$ and phosphorus (P) losses, (2) cover crops can reduce soil erosion significantly, and (3) cover crops can improve soil productivity (table 2). These are viewed as measures of both the relative advantage and the behavioral beliefs-attitude components of the framework (figure 1). The items, which align with perceived benefits identified by Conservation Technology Information Center/Sustainable Agriculture Research and Education (CTIC/SARE) farmer surveys (CTIC 2013, 2014), represent farmers' ratings of the relative benefits of cover crops compared to an absence of cover crops, which in turn can influence beliefs about the potential consequences of cover crop use and a positive or negative attitude toward cover crops. The scale has a Cronbach's reliability coefficient of 0.79 , which is considered to be more than adequate (Field 2009).

The perceived risks scale is composed of seven items that measure farmers' perceptions of risks associated with cover crop use and compatibility with current production systems. The items are (1) cover crop water use can pose a risk to yields in dry years; (2) cover crops can complicate crop insurance; (3) cover crops can delay spring planting; (4) cover crops reduce yields in crops that follow; (5) the expenses of cover crops outweigh the potential benefits; (6) I'm not convinced cover crops are right for my farm; and (7) there is rarely enough time between harvest and winter to justify the use of cover crops (table 2). Items 1, 3, 4, and 5 also align with the behavioral beliefs-attitude component of the conceptual framework as they could be expected to influence beliefs about consequences of cover crop use and therefore shape attitudes toward them (figure 1). Items 2 and 7 align with the control beliefs-self-efficacy components of the conceptual framework because weather and crop insurance are factors that are to some degree out of farmers' control, yet could shape outcomes associated with cover crop use. The scale has a Cronbach's reliability coefficient of 0.76 .

The potential facilitators scale is composed of five items that primarily measure elements of control beliefs and self-efficacy. The items are (1) if trusted agricultural advisers (ag retailers, seed dealer, extension, etc.) could help me with cover crop management, I would be more likely to use cover crops; (2) I would like to learn more about using cover crops; (3) if there were more custom operators with capacity to plant cover crops, more farmers would use cover crops; (4) if cover crops could be easily planted before harvest (i.e., aerial seeding, highboy), I would be more likely to use them; and (5) landlords' lack of knowledge of or support for cover crops is a barrier to cover crop use (table 2). These items measure dimensions of farmers' perceptions of how different factors might facilitate or serve as barriers to cover 
Table 2

Means and percentage distributions for perceived characteristics of cover crops.

\begin{tabular}{|c|c|c|c|c|c|c|c|}
\hline Scale and items & Mean & SD & $\begin{array}{l}\text { Strongly } \\
\text { disagree (\%) }\end{array}$ & $\begin{array}{l}\text { Disagree } \\
(\%)\end{array}$ & $\begin{array}{l}\text { Uncertain } \\
\text { (\%) }\end{array}$ & $\begin{array}{l}\text { Agree } \\
(\%)\end{array}$ & $\begin{array}{l}\text { Strongly } \\
\text { agree (\%) }\end{array}$ \\
\hline Perceived benefits $\alpha=0.794$ & 3.82 & 0.558 & & & & & \\
\hline $\begin{array}{l}\text { Cover crops can reduce nitrogen and } \\
\text { phosphorus losses }\end{array}$ & 3.78 & 0.668 & 0.1 & 2.6 & 27.5 & 59.0 & 10.7 \\
\hline $\begin{array}{l}\text { Cover crops can reduce soil erosion } \\
\text { significantly }\end{array}$ & 3.96 & 0.674 & 0.3 & 2.5 & 15.5 & 64.6 & 17.1 \\
\hline Cover crops can improve soil productivity & 3.72 & 0.644 & 0.0 & 2.2 & 31.9 & 57.4 & 8.5 \\
\hline Perceived risks $\alpha=0.759$ & 3.10 & 0.517 & & & & & \\
\hline $\begin{array}{l}\text { Cover crop water use can pose a risk } \\
\text { to yields in dry years }\end{array}$ & 3.10 & 0.787 & 2.4 & 16.9 & 52.0 & 26.2 & 2.5 \\
\hline $\begin{array}{l}\text { Cover crops can complicate crop } \\
\text { insurance }\end{array}$ & 3.15 & 0.728 & 1.4 & 11.8 & 61.7 & 20.9 & 4.2 \\
\hline Cover crops can delay spring planting & 3.17 & 0.852 & 2.0 & 18.9 & 43.9 & 30.8 & 4.5 \\
\hline $\begin{array}{l}\text { Cover crops reduce yields in crops } \\
\text { that follow }\end{array}$ & 2.72 & 0.765 & 3.8 & 31.3 & 55.5 & 7.9 & 1.5 \\
\hline $\begin{array}{l}\text { The expenses of cover crops outweigh } \\
\text { the potential benefits }\end{array}$ & 2.97 & 0.765 & 3.2 & 18.2 & 59.9 & 15.8 & 3.0 \\
\hline $\begin{array}{l}\text { I'm not convinced cover crops are } \\
\text { right for my farm }\end{array}$ & 3.09 & 0.909 & 4.6 & 19.4 & 42.9 & 29.0 & 4.1 \\
\hline $\begin{array}{l}\text { There is rarely enough time between } \\
\text { harvest and winter to justify the } \\
\text { use of cover crops }\end{array}$ & 3.50 & 0.913 & 1.3 & 13.7 & 30.4 & 43.1 & 11.4 \\
\hline Potential facilitators $\alpha=0.705$ & 3.30 & 0.542 & & & & & \\
\hline $\begin{array}{l}\text { If trusted agricultural advisers } \\
\text { (ag retailers, seed dealer, extension, } \\
\text { etc.) could help me with cover crop } \\
\text { management, I would be more likely } \\
\text { to use cover crops }\end{array}$ & 3.23 & 0.804 & 2.1 & 15.2 & 42.7 & 37.9 & 2.1 \\
\hline $\begin{array}{l}\text { I would like to learn more about using } \\
\text { cover crops }\end{array}$ & 3.45 & 0.806 & 1.6 & 10.0 & 34.8 & 48.4 & 5.2 \\
\hline $\begin{array}{l}\text { If there were more custom operators } \\
\text { with capacity to plant cover crops, } \\
\text { more farmers would use cover crops }\end{array}$ & 3.28 & 0.814 & 2.0 & 13.0 & 44.3 & 36.6 & 4.1 \\
\hline $\begin{array}{l}\text { If cover crops could be easily planted } \\
\text { before harvest (i.e., aerial seeding, } \\
\text { highboy), I would be more likely to } \\
\text { use them }\end{array}$ & 3.32 & 0.801 & 1.3 & 13.2 & 42.2 & 39.2 & 4.1 \\
\hline $\begin{array}{l}\text { Landlords' lack of knowledge of or } \\
\text { support for cover crops is a barrier } \\
\text { to cover crop use }\end{array}$ & 3.23 & 0.794 & 1.3 & 15.3 & 45.7 & 34.2 & 3.4 \\
\hline
\end{tabular}

Note: $\alpha=$ Cronbach's reliability coefficient.

crop use. The scale had a Cronbach's reliability coefficient of 0.71 .

A fourth scale measures farmers' awareness and concern about the impacts of nutrients and attitudes toward potential ameliorative actions. These concepts are central in the contextual factors component of the conceptual framework (figure 1). Awareness of environmental problems and attitudes toward potential solutions are among the few variables that reviews of conservation adoption research have found to be fairly consistent predictors of conservation behavior (Baumgart-Getz et al. 2012; Knowler and Bradshaw 2007; Prokopy et al. 2008). Seven items are included in the scale: (1) Iowa farmers should do more to reduce nutrient and sediment runoff into waterways; (2) I am concerned about agriculture's impacts on Iowa's water quality; (3) nutrients from Iowa farms contribute to hypoxia in the Gulf of Mexico; (4) I would be willing to have someone help me to evaluate how my farm operation is doing in terms of keeping nutrients out of waterways; (5) helping to meet the Nutrient Reduction Strategy's goals is a high priority for me; (6) I would like to improve conservation practices on the land I farm to help meet the Nutrient Reduction Strategy's goals; and, (7) fertilizer and ag chemical dealers should do more to help farmers address nutrient losses into waterways (table 3). Considered together, these items comprise a robust measure of both awareness of agriculture's impacts on water quality and general attitudes toward conservation behavior to address those impacts. The scale has a Cronbach's reliability coefficient of 0.81

A number of variables measure other components of the contextual factors section of the conceptual framework. Following Singer et al. (2007), number of crop types planted in 2013 is included as an indicator of cropping system diversity associated with 
Table 3

Means and percentage distributions for items that form the awareness and concern scale.

\begin{tabular}{|c|c|c|c|c|c|c|c|}
\hline Scale and items & Mean & SD & $\begin{array}{l}\text { Strongly } \\
\text { disagree (\%) }\end{array}$ & $\begin{array}{l}\text { Disagree } \\
(\%)\end{array}$ & $\begin{array}{l}\text { Uncertain } \\
\text { (\%) }\end{array}$ & $\begin{array}{l}\text { Agree } \\
(\%)\end{array}$ & $\begin{array}{l}\text { Strongly } \\
\text { agree (\%) }\end{array}$ \\
\hline Awareness and concern $\alpha=0.806$ & 3.66 & 0.524 & & & & & \\
\hline $\begin{array}{l}\text { lowa farmers should do more to reduce } \\
\text { nutrient and sediment runoff into } \\
\text { waterways }\end{array}$ & 4.04 & 0.659 & 0.2 & 2.0 & 12.6 & 64.0 & 21.2 \\
\hline $\begin{array}{l}\text { I am concerned about agriculture's } \\
\text { impacts on lowa's water quality }\end{array}$ & 3.87 & 0.741 & 0.8 & 4.0 & 18.3 & 61.6 & 15.3 \\
\hline $\begin{array}{l}\text { Nutrients from lowa farms contribute to } \\
\text { hypoxia in the Gulf of Mexico }\end{array}$ & 3.57 & 0.801 & 0.8 & 6.3 & 39.5 & 42.2 & 11.1 \\
\hline $\begin{array}{l}\text { I would be willing to have someone help } \\
\text { me to evaluate how my farm operation } \\
\text { is doing in terms of keeping nutrients } \\
\text { out of waterways }\end{array}$ & 3.35 & 0.891 & 4.2 & 10.0 & 38.3 & 41.7 & 5.8 \\
\hline $\begin{array}{l}\text { Helping to meet the Nutrient Reduction } \\
\text { Strategy's goals is a high priority for me }\end{array}$ & 3.40 & 0.830 & 1.6 & 11.5 & 38.4 & 42.4 & 6.0 \\
\hline $\begin{array}{l}\text { I would like to improve conservation } \\
\text { practices on the land I farm to help meet } \\
\text { the Nutrient Reduction Strategy's goals }\end{array}$ & 3.77 & 0.667 & 0.3 & 3.8 & 23.0 & 64.3 & 8.5 \\
\hline $\begin{array}{l}\text { Fertilizer and ag chemical dealers should } \\
\text { do more to help farmers address } \\
\text { nutrient losses into waterways }\end{array}$ & 3.57 & 0.785 & 0.8 & 8.7 & 30.6 & 52.4 & 7.5 \\
\hline
\end{tabular}

each farmer's operation. Survey questions measured acres of corn, soybeans, other field crops (e.g., small grains, vegetables), and pasture/hay. These were each assigned a value of 1 if the respondent reported production and a zero if not. The variables were summed to create a scale that ranged from 0 to 4 (table 4). Singer et al. (2007) also found that livestock production was a significant predictor of cover crop adoption, likely associated with potential use for forage. A dichotomous measure of livestock production (Yes $=1$ ) is also included in the model.

Additional farm-level characteristics are included. Cover crops are generally only appropriate for land planted to field crops, so a dichotomous measure of field crops is included as a control variable (table 4). A dichotomous measure of whether farmers rented land in 2013 is also included as there is evidence that some conservation practices are less likely to be used on rented land than on owned land (Carolan 2005; Soule et al. 2000). Finally, a 10-category gross farm sales scale ranging from US\$0 (1) to more than US $\$ 1$ million (10) is employed as an indicator of available financial resources, which have been found to be a positive predictor of practice adoption (Baumgart-Getz et al. 2012). Farmer age is also included as it has been found to be a consistent predictor of conservation behavior, although not always consistently in the same direction, depending on the type of practice being evaluated
(Knowler and Bradshaw 2007). However, Baumgart-Getz et al's review (2012) found that older farmers are typically less likely to engage in conservation practices.

Two variables focus on the networks component of farming context. Trusted advisors, including crop advisors and information sources, can influence behavior (BaumgartGetz et al. 2012; Lemos et al. 2014; Prokopy et al. 2013). Baumgart-Getz et al. (2012) found that educational resources from extension can be positively associated with conservation practice adoption. Additionally, private agricultural advisors have been found to be important for farmers adopting new technologies and gaining essential information on new practices (Prokopy et al. 2013).

The two networks variables measured trust in private sector advisors and extension as sources of crop-related information (table 4). Farmers were provided a list of six crop-related topics (fertilizer type, fertilizer timing, fertilizer application rates, insect pest management, weed management, and crop disease management), given a list of agricultural advisors, and asked to rate which one they trusted most for each type of information. One variable is the sum of the number of times any of three private sector sources of information-fertilizer or ag chemical dealer, seed dealer, and private crop consultant-were cited as the most trusted source of information on the six crop-related topics. The second is the sum of number of times that Iowa State University Extension was cited as the most trusted source.

Expected Relationships. In summary, it is useful to explicitly state the expected relationships between the dependent variable-cover crop use-and the covariates in the regression model. The following research expectations are proposed. Positive relationships are expected between cover crop use and the following variables:

- perceived benefits scale,

- potential facilitators scale,

- awareness and concern scale,

- number of crops planted,

- livestock,

- trust in extension for crop management information,

- age, and

- gross farm sales.

Negative relationships are expected between cover crop use and the following variables:

- perceived risks scale,

- trust in private sector for crop management information, and

- rents land.

\section{Results and Discussion}

Descriptive Statistics. Seventeen percent of farmers in the sample reported that they had planted cover crops in 2013. Among the covariates, scores on the perceived benefits scale (mean 3.82 out of 5) reflect substantial agreement that cover crops are beneficial (table 2). More than $80 \%$ agreed 


\section{Table 4}

Farm and farmer characteristics.

\begin{tabular}{|c|c|c|c|c|c|}
\hline Variable & Item & Mean & SD & Minimum & Maximum \\
\hline Covers13 & Used cover crops in 2013 (Yes = 1) & 0.17 & 0.375 & 0 & 1 \\
\hline Trust in private entities & $\begin{array}{l}\text { Number of crop management info areas in which private sector } \\
\text { trusted most }\end{array}$ & 4.12 & 2.40 & 0 & 6 \\
\hline Trust in extension & $\begin{array}{l}\text { Number of crop management info areas in which private sector } \\
\text { trusted most }\end{array}$ & 1.13 & 1.97 & 0 & 6 \\
\hline Number of crops & $\begin{array}{l}\text { Sum of corn, soybeans, other field crops (e.g., small grains, } \\
\text { vegetables), and pasture/hay planted in } 2013\end{array}$ & 2.20 & 0.844 & 0 & 4 \\
\hline Livestock & Had livestock in 2013 (Yes = 1) & 0.31 & 0.462 & 0 & 1 \\
\hline Rents land & Whether the farmer rented land in $2013($ Yes = 1) & 0.54 & 0.499 & 0 & 1 \\
\hline Gross farm sales & $\begin{array}{l}\text { 10-category measure of gross farm revenue from zero }(0) \\
\text { to } 1 \text { million+ (10) }\end{array}$ & 6.49 & 2.07 & 1 & 10 \\
\hline Age & Age of farmer & 64.19 & 10.73 & 28 & 91 \\
\hline
\end{tabular}

that cover crops can reduce soil erosion significantly, and nearly $70 \%$ agreed that they can reduce losses of $\mathrm{N}$ and $\mathrm{P}$. About twothirds agreed that cover crops can improve soil productivity.

The mean score of 3.10 out of 5 on the perceived risks scale reflects lower levels of agreement with statements about potential risks associated with cover crop use, but considerable uncertainty (table 2). Substantial majorities of farmers either agreed with or were uncertain about the seven items that evaluated the degree to which they view cover crops as a risk to production or profitability.

The results for the potential facilitators scale (mean 3.30 out of 5 ) show that most respondents $(54 \%)$ indicated that they would like to learn more about cover crops, and many agreed that more support for cover crop use within their professional and technical advisory networks would make cover crop use more likely (table 2). As with the perceived risks scale, however, there was substantial uncertainty: it appears that many farmers simply do not know what to think about the prospect of greater technical support for cover crops adoption.

The mean score of 3.66 on the awareness and concern scale is evidence of substantial levels of awareness about agriculture's impact on the environment and positive attitudes toward actions to ameliorate those impacts. More than $85 \%$ of respondents agreed that Iowa farmers should do more to reduce water quality impacts, and more than $75 \%$ expressed concern about those impacts (table 3). Further, more than $70 \%$ indicated willingness to improve conservation practices on the land they farm.

The descriptive statistics for farm characteristics and farming context are presented in table 4. Average number of crops planted in 2013 was 2.2. Ninety percent of respondents reported field crops in 2013, and 54\% reported that they had rented land. Thirtyone percent had livestock. The average gross farm sales category was 6.5 , which roughly equates to somewhere between category six (US $\$ 100,000$ to US $\$ 250,000$ ) and seven (US\$251,000 to US\$500,000). The average age of farmers in the sample was 64 .

The mean number of types of information for which farmers trust private sector entities most was 4.1 (table 4). The mean number of types of information for which farmers trust extension the most was 1.3.

Logistic Regression Results. We employed binary logistic regression to model adoption of cover crops. Binary logistic regression is an appropriate approach when a dependent variable is a dichotomous measure of group membership, in this case, cover crop adopters (1) and nonadopters (0). It is a multivariate regression technique that, similar to ordinary least squares multiple regression, is used to estimate the relative impact of multiple predictor variables on a dependent variable (Hair et al. 2010).

Model fit statistics were acceptable. The Hosmer and Lemeshow test statistic of 5.551 was not significant $(p=0.697)$, which indicates good model fit (table 5). The Nagelkerke $r^{2}$ of 0.247 indicates that the covariates explain a substantial amount of variance in the dependent variable. Listwise deletion of cases with missing values on at least one variable reduced the sample size from 960 to 789 .

The relationships between the dependent variable, use of cover crops in 2013, and the covariates largely aligned with expectations as diagrammed in the conceptual framework and outlined above. Table 5 reports the logistic coefficients (B), the standard error of the coefficients (SE), and the exponentiated coefficients (Exp[B]), also referred to as odds ratios (Field 2009). Statistical significance of variables in the model is reported using the conventional asterisks on the coefficients. Direction and magnitude of the relationships between the predictor variables and cover crop adoption can be assessed by interpreting the odds ratio values. Odds ratio values over 1 indicate a positive relationship, and values below 1 indicate a negative relationship (Hair et al. 2010).

All three scales that examined components of perceived practice characteristics and behavioral/normative/control beliefs specific to cover crops were strong predictors of cover crop use (table 5). As expected, farmers with higher scores on the perceived benefits scale were more likely to have planted cover crops in 2013. Conversely, farmers with higher scores on the perceived risk scale were less likely to have planted cover crops. The third cover crop-specific scale-potential facilitators - was also positively related to cover crop use. These results aligned well with the research expectations and indicate that farmers who perceived a relative advantage associated with cover crop use and who had positive behavioral beliefs about the potential consequences of cover crop use were more likely to use them. Conversely, those farmers who perceived more risk, incompatibility, and who had negative behavioral and control beliefs were much less likely to have reported cover crop use.

Contrary to expectations, the awareness and concern scale was not a significant predictor of cover crop use (table 5). A possible explanation for the lack of significance could 
be that the scale items, which were drawn from a question set focused on Iowa's new Nutrient Reduction Strategy, were narrowly centered on awareness and concern about water quality, rather than conservation more broadly conceived to encompass soil health and erosion. Given that farmers place equal or greater emphasis on the erosion control and soil productivity benefits of cover crops (see table 3), it may be that the measure of water quality awareness and concern was not appropriate for the model. The other individual-level contextual factor, age, was not significant either.

Among the farm characteristics variables, number of crop types and livestock production were significant predictors of cover crop use (table 4). Farmers with more diverse cropping systems were substantially more likely to have planted cover crops in 2013. Likewise, farmers who reported having livestock were more likely to have adopted cover crops. Among the farm characteristics variables included as controls, only gross farm sales was significant, indicating that larger-scale farmers were more likely to have used cover crops. Neither of the measures of farming context that focused on agricultural social networks (trust in in private and extension information sources) were significantly associated with cover crop use.

Interview Results. Data from the interviews assists in the interpretation of the quantitative results and provides qualitative insight into participants' perspectives on cover crops. The qualitative data analysis focuses on the findings at the center of the conceptual framework: perceived practice characteristics. The presentation of qualitative results follows the order in which the quantitative results were presented.

The survey results for the "perceived benefits" scale and its component items indicate that many Iowa farmers perceive a relative advantage associated with cover crop use and believe that cover crops can provide agronomic and environmental benefits. The results of the regression analysis suggest that these beliefs and attitudes are strongly associated with a greater likelihood of cover crop adoption. The interview data provide detailed explanations of the perceived value of cover crops in respondents' farm operations. For this subsection, only data from farmers who had used cover crops are presented.

The three concepts that the survey items measured-reduction of nutrient loss, increasing soil fertility, and reducing

\section{Table 5}

Logistic regression results: planted cover crops in $2013($ Yes $=1)$.

\begin{tabular}{lcll}
\hline Predictor variables & B & SE & Exp(B) \\
\hline Constant & $-4.502 * *$ & 1.734 & 0.004 \\
Perceived benefits & $0.635 * *$ & 0.243 & 1.981 \\
Perceived risks & $-1.083^{* * *}$ & 0.219 & 0.279 \\
Potential facilitators & $0.419 *$ & 0.225 & 1.521 \\
Awareness and concern & 0.298 & 0.267 & 1.348 \\
Trust in private entities & -0.115 & 0.070 & 0.885 \\
Trust in extension & -0.120 & 0.081 & 0.889 \\
Number of crops & $0.430 * *$ & 0.161 & 1.574 \\
Livestock (Yes $=1)$ & $0.551 *$ & 0.238 & 1.674 \\
Cropland 2013 (Yes $=1)$ & -0.658 & 0.536 & 0.473 \\
Rents land (Yes $=1)$ & -0.430 & 0.240 & 0.647 \\
Gross farm sales & $0.299 * * *$ & 0.071 & 1.353 \\
Age & -0.005 & 0.010 & 0.992 \\
\hline$n$ & 789 & & \\
Nagelkerke $r^{2}$ & 0.247 & & \\
Percentage correctly classified & $85.3 \%$ & & \\
Hosmer and Lemeshow & $p=0.697$ & & \\
Model $\chi^{2}, d f 12$ & $125.134 * * *$ & \\
$* * 0.05$ & & & \\
$* * p<0.01$ & & & \\
$* * * p<0.001$ & & & \\
& & & \\
\hline
\end{tabular}

erosion-were mentioned by nearly all farmers who had adopted cover crops. In addition, the benefits were generally mentioned together, with farmers emphasizing the linkages between the types of benefits. One farmer noted the relationship between all three benefits:

Building tilth in the soil...that's going to be the main thing that a farmer's going to say, or, where's the payback on this...how can I make that soil more resilient or able to handle the stresses...By having that structure and those roots there and...holding on to that soil and maybe, hold on to more nutrients... if we can keep those loose nutrients out of our water and use them to build organic matter...then that'll be a plus.

Another focused on erosion and soil health: The oats would die over the winter itself so you wouldn't have to spend any money on killing it off in the spring. And we have a lot less washing after we seed the oats when we chop the corn silage... You get more microbial activity when you have that oats in there. The ground is really nice and mellow, and it's nice to plant in so you're going to get a yield boost from it.

Other farmers emphasized the erosion abatement benefits:

Well, we had a neighbor that used to put rye on corn he chopped... and I kind of laughed. But then we had a winter where the frost went out the first part of February and... the top two inches thawed out and then we had heavy rain. And it started washing where there was nothing...I didn't laugh anymore. I was like, "we have to do something." So that's how we got started.

These quotes are illustrative of how farmers think about the benefits of cover crops in their agricultural systems. They articulate the relative advantages of cover crops clearly: compared to whatever they were doing before, cover crops were perceived to be providing superior erosion control, soil heath, and nutrient loss reduction benefits.

The survey results for the "perceived risk" scale and its component items show that many Iowa farmers have concerns about potential incompatibilities and risks associated with cover crop use. The results of the regression analysis indicate that higher levels 
of perceived risks are associated with a lower likelihood of cover crop adoption. Because perceptions about risks can influence control beliefs, or beliefs about capacity to use cover crops successfully, thorough understanding of those perceptions is important. The qualitative data provided detailed information on what kinds of risks farmers believe cover crop use might entail. For this subsection, data from both farmers who had used cover crops and farmers who had not are presented.

For most of the farmers who were interviewed, negative interaction between cover crops and climatic conditions was a predominant concern. These issues focused primarily on compatibility between cover crops and timing of fieldwork in relation to weather. One farmer who had never planted cover crops expressed this concern:

The reason I don't is because when I get done picking corn, I got to get in there and get the bales made and then I got to haul a lot of manure "cause I pile everything in the summer... by the time I'm done, a cover crop wouldn't do me any good.

Another farmer who had not used cover crops expressed concern about interaction between temperatures and herbicide products, and resulting risk to yields:

The potential problem of having trouble getting them killed in the spring. If you have a cold snap when you're trying to get them killed, they might not be active enough where they get a good takeup of that Roundup...so, potential for them to compete... and then...you'll have not as much nitrogen available as what should be for that corn.You'll stunt the corn, potentially, and stuff.

Other farmers who had not used cover crops perceived a short window between harvest and the onset of weather too cold to allow establishment:

If we have time, you know. If it gets so late in the fall that you don't even have the thing harvested yet, well that cover crop thing's going to be hard to do.

and

It would be a challenge to get it on in the fall early enough to get it to grow, I would think.
Farmers also perceived a potential competition for moisture:

That's the only downfall I see in cover crops...it's going to suck some moisture out. They say it don't, but it does something... and once you get that off in there and it turns out dry, you're hurting.

Another farmer explained how lack of certainty and knowledge about potential benefits can deter farmers from trying cover crops:

I haven't seen the benefits yet, I mean... I've heard from the neighbors who are starting to think about doing it and I just haven't figured it out why yet. So, on flat ground, I don't... If it was rolling hills, I would, probably but...

Even farmers who had used cover crops highlighted some of the risks involved with using them, as this passage illustrates:

It worked well for holding the soil. [But] we didn't get the oats killed quick enough and the corn and that on those hillside areas didn't do so well. But that, you know, that was our fault for not getting that killed off quick enough...I mean, cover crops definitely, I think, hold a lot of promise but I think there's going to be a learning curve there, definitely.

These quotes align with the survey findings and add depth to our understanding of some key barriers that farmers perceive while also illustrating that there is a learning curve associated with adopting cover crops. Issues of complexity, and compatibility with their current production system(s) lead to perceived risks, particularly concerns about potential negative yield impacts.

The descriptive statistics for the "potential facilitators" items and scale show that many Iowa farmers believe that if more facilitating infrastructure-educational, institutional, and technical-were available to them, they would be more likely to use cover crops. The regression results indicated that farmers who scored higher on the scale were more likely to have used cover crops. The data from the in-depth interviews echo those findings, and provide further insight.

Three farmers who had tried cover crops discussed the role that facilitating factors had played in their decision to use cover crops. Two explained how both external funding and interaction with a watershed group had influenced them:

Well, actually, you know, a combination of the watershed [group], and then we did an EQIP [Environmental Quality Improvement Program] program and, you know, there was some incentives to do some cover crops with that so we signed up for a plan on one of the larger farms...to do cover crop the year it's in soybeans. So I was kind of watching that and see how that works, whether... whether I continue to add more or not.

and

...maybe more good funding for the watershed groups. I mean, that's really a good way to get this...this stuff started...get exposed to some of these different practices and get to discuss, you know, how they work with the other guys and, you know, you can see kind of what the results are, how things, you know, how it worked out.

A third farmer related how cost-share had helped him to make the decision to try cover crops for the first time:

But now, this year, I did qualify through the MRBI [Mississippi River Basin Initiative]... They're going to pay for the cover crop on that. And then, through the EQIP, I'm getting some money for the home farm for the cover crop. See, yeah, they've assisted me, not last year, but they will in 2013 with doing some more cover crops. So, but after that...I won't qualify for any from what I understand. And that's fine. I just think it's going to be a good thing, and I'm going to continue doing it.

Another farmer discussed his experience with facilitating factors that did not match his needs, leading to a suboptimal cover crop experience. He wanted to try aerial seeding, but the local plane was not equipped for the type of seed he wanted to plant:

...so I was going to have it flown on with an airplane, okay. So the guy I talked to he said, well, my plane is set up for rye grass, not rye grain. Well I wanted to plant rye grain cause that stuff will grow. You can throw it on a table and that stuff will grow. But his 
plane was set up for rye grass. So I... bought 10 bags of [rye grass]... So the guy flew it on, but then it didn't rain. Well then when I went out to harvest...I expected the ground to be green but it wasn't... Well now, looking back at it, oh, you should have planted rye grain not rye grass.

From this farmer's point of view, the lack of appropriate infrastructure, in this case a plane that could handle his preferred seed variety, resulted in a cover crop experience that did not meet expectations.

A fourth area for which the interview data help to fill out findings from the logistic regression is "livestock and crop diversity." Livestock and crop diversity are discussed together because crop diversity (i.e., incorporation of hay or pasture, small grains, or other crops) is often associated with livestock production, and integrated crop-livestock systems are typically more diverse than the specialized commodity grain farms that have become predominant in Iowa (Arbuckle et al. 2009). Interview participants' tendency to discuss crop diversity and livestock together reflected those links.

Farmers discussed how cover crops fit into their crop-livestock systems. Some extolled the forage value of cover crops, highlighting their compatibility with their systems:

We milk cows. We grow corn three years. Hay, 3 to 4 years. Oats, [one] year. We put cover crops in after we chop the corn silage. Usually oats and seed the alfalfa in it. Sometimes we put rye in in the fall. Depends on if we're short on feed or not;

and

But then my hope is to get an extra crop for the cows and that's my main goal. Get another crop for the cows. And if it benefits the soil tilth and prevents erosion a little bit, that's great too;

and

Well, we didn't want to leave the ground unprotected....and we thought...we could...pick up a couple weeks of grazing with the cows too, which we did. We sowed oats then because we didn't have to fight it in the spring, you know, it would die out over the winter.
These quotes, together with the logistic regression results showing that farmers with livestock were more likely to report using cover crops, suggest that the perceived benefits of cover crops are higher in mixed crop-livestock systems. The possibility of forage for livestock, in addition to the erosion control and soil health benefits, may add an important short-term economic benefit to the longer-term advantages of cover crops.

\section{Summary and Conclusions}

The results of the quantitative and qualitative data analysis provide insight into the roles that perceived practice characteristics, perspectives on potential facilitating factors, and crop and livestock diversity play in cover crop adoption decisions among Iowa farmers. As expected, perceived benefits were positive predictors of cover crop use. Measures of crop and livestock diversity were also positive predictors of adoption. In addition, farmers who endorsed strengthening of facilitating factors such as educational and technological infrastructure to support cover crop use were more likely to have planted cover crops in 2013. Perceived risks, on the other hand, were negatively associated with cover crop adoption.

The results of both the quantitative and qualitative research highlight the critical importance of perceived benefits as determinants of cover crop use. The survey data indicated that most respondents believed that cover crops can provide benefits such as reductions in soil erosion and nutrient loss, while enhancing soil productivity. Interview data provided details about how beliefs regarding multiple cover crops benefits can influence the decision to try cover crops. They also pointed to moments of "realization" in which farmers determined that cover crops were needed to address problems such as soil erosion or otherwise maintain or enhance the resilience of their soil resource.

In contrast, higher levels of perceived risks were negatively related to cover crop adoption. The survey data indicated that most Farm Poll participants associated a number of risks with cover crops. Both the survey and interview data suggested that beliefs about weather-related threats to successful cover crop establishment and/or termination and related negative impacts on yield are substantial impediments to cover crop use. The qualitative data also pointed to a potential interaction between lack of knowledge and perceptions of risk and uncertainty associated with the idea of using cover crops.

The positive relationship between farmers' evaluations of potential facilitators of cover crops and cover crop adoption indicates that cover crop users believe that more effort should be put into education among farmers and agricultural advisors. The survey results showed that many farmers would like to learn more about cover crops, and many agreed that if technical assistance were more widely available, more farmers would use cover crops. Data from the interviews support those findings, as farmers who had used cover crops noted that the support that they had received from conservation agencies and watershed groups had been instrumental in their decision and capacity to adopt them. It may be that many farmers who had adopted cover crops either benefited from support, would like to have had more support, or both. Regardless, the positive relationship between endorsement of improvement of facilitating infrastructure and cover crops adoption suggests that more attention should be focused on this area.

The quantitative and qualitative results suggest that crop and livestock diversity is strongly related to perceived benefits, especially for operations with livestock. The interview data indicated that farmers with diverse systems perceived higher levels of compatibility between their systems and cover crops. For livestock producers, the potential short-term benefit of extra forage appeared to be an important compatibility consideration that tipped the scales in favor incorporating cover crops. Singer et al. (2007) also found that crop diversity and integrated crop and livestock systems were critical factors in explaining adoption of cover crops. These results suggest that increasing diversity and integration of livestock in cropping systems could further facilitate cover crop adoption while providing additional landscape-level benefits (e.g., weed/insect suppression or extreme weather mitigation) that come with a more diversified agricultural system (Davis et al. 2012; Kremen and Miles 2012; Lin 2011).

Finally, farm size, as measured by gross farm sales, was a positive predictor of cover crop use. The interpretation of this result is not clear. It may be, as a number of studies (Lockeretz 1009; Prokopy 2008) have suggested, that such farms have more resources to dedicate to conservation. Nevertheless, 
since larger-scale farmers farm a disproportionate amount of land relative to their numbers, if they are more likely to adopt cover crops than smaller-scale farmers, then cover crops promotional efforts targeting larger farmers might result in a bigger payoff in terms of acres planted to cover crops.

Considered together, the findings have important implications for efforts to promote cover crops. First, the results suggest that it is not enough to have positive views about the benefits of cover crops. Most farmers in our sample perceived benefits of cover crops, yet a minority had adopted them, likely due to the countervailing strength of perceived risks. Evidence from the interviews suggests that events can lead to a tipping point at which the potential benefits outweigh the perceived risks (e.g., "... and it started washing where there was nothing...I didn't laugh anymore. I was like, 'we have to do something."') and farmers become willing to try cover crops. Such events and associated realizations can serve as catalysts that influence changes in behavior (Prokopy et al 2014). However, our results indicate that farmers may need to have a solid understanding of both the benefits and the risks of cover crops in order to pass such a tipping point and make the decision to try them.

Cover crops promotional materials tend to highlight the potential benefits of cover crop use more than the potential risks (e.g., Bryant et al. 2013; Clark 2007). The results of this research indicate that awareness of the benefits of cover crops is an important, but perhaps not sufficient, condition for spurring adoption. The results of this study suggest that research and promotional efforts should also prioritize (1) quantifying and communicating the potential risks and costs of cover crop use, and (2) developing technical assistance and other facilitating infrastructure. Better understanding of potential risks, and ways that those risks can be managed, might help farmers to more effectively evaluate the costs and benefits of cover crops and how they might be integrated into their operations. Results also suggest that improved infrastructure to support cover crop adoption (i.e., availability of seed, equipment, expertise, etc.) would lead more farmers to consider cover crops as an option. Research and extension efforts that address all three of these challenges - raising awareness of benefits, increasing risk management capacity, and enhancing facilitating infrastructure-will likely lead to more widespread cover crop use.

\section{Acknowledgements}

This research was funded in part by the Iowa Agriculture and Home Economics Experiment Station at Iowa State University and supported by the USDA National Institute of Food and Agriculture (NIFA) Award no. 2011-68002-30190, Cropping Systems Coordinated Agricultural Project: Climate Change, Mitigation, and Adaptation on Corn-based Cropping Systems project. Project website: www.sustainablecorn.org.

\section{References}

Ajzen, I. 1991. The theory of planned behavior. Organizational Behavior and Human Decision Processes 50(2):179-211.

Arbuckle, J.G., and J. Ferrell. 2012. Attitudes toward Cover Crops in Iowa: Benefits and Barriers. Iowa Farm and Rural Life Poll. Ames, IA: Iowa State University Extension and Outreach.

Arbuckle, J.G., P. Lasley, P. Korsching, and C. Kast. 2009. Summary report Iowa Farm and Rural Life Poll. Ames, IA: Iowa State University Extension.

Basche, A., F. Miguez, T. Kasper, and M. Castellano. 2014. Do cover crops increase or decrease nitrous oxide emissions in agroecosystems? A meta-analysis. Journal of Soil Water Conservation 69(6):471-482, doi:10.2489/ jswc.69.6.471.

Baumgart-Getz, A., L.S. Prokopy, and K. Floress. 2012. Why farmers adopt best management practice in the United States: A meta-analysis of the adoption literature. Journal of Environmental Management 96:17-25.

Bryant, L., R. Stockwell, and T. White. 2013. Counting Cover Crops. Washington, DC: National Wildlife Federation.

Carlson, S., and R. Stockwell. 2013. Research priorities for advancing adoption of cover crops in agricultureintensive regions. Journal of Agriculture, Food Systems, and Community Development 3(4):125-29.

Carolan, M.S. 2005. Barriers to the adoption of sustainable agriculture on rented land: An examination of contesting social fields. Rural Sociology 70(3):387-413.

CENR (Committee on Environment and Natural Resources). 2010. Scientific Assessment of Hypoxia in US Coastal Waters. Washington, DC: Interagency Working Group on Harmful Algal Blooms, Hypoxia, and Human Health of the Joint Subcommittee on Ocean Science and Technology.

Chatterjee, A. 2013. North-Central US: Introducing cover crops in the rotation. Crops and Soils, 46(1):14-15.

Clark, A. (ed.). 2007. Managing Cover Crops Profitably, 3rd ed. Sustainable Agriculture Network, Beltsville, MD.

Corbin, J., and A. Strauss.1990. Grounded theory research: Procedures, canons, and evaluative criteria. Qualitative Sociology 13(1):3-21.

CTIC (Conservation Technology Information Center). 2013. Report of the 2013-2014 Cover Crop Survey. West
Lafayette, IN: Conservation Technology Information Center and Sustainable Agriculture Research and Education.

CTIC. 2014. 2012-2013 Cover Crop Survey. West Lafayette, IN: Conservation Technology Information Center and Sustainable Agriculture Research and Education.

Davis, A.S., J.D. Hill, C.A. Chase, A.M. Johanns, and M. Liebman. 2012. Increasing cropping systems diversity balances productivity, profitability and environmental health. PLOS One 7(10):e47149, doi: 10.1371/journal. pone.0047149.

DeVellis, R.F. 2003. Scale development: Theory and applications. Thousand Oaks, CA: Sage.

Field, A. 2009. Discovering Statistics Using SPSS. Thousand Oaks, CA: Sage Publications.

Fishbein, M., and I. Ajzen. 2010. Predicting and Changing Behavior: The Reasoned Action Approach. New York, NY: Psychology Press.

Fliegel, F.C. 1993. Diffusion Research in Rural Sociology: The Record and Prospects for the Future. Westport, CT: Greenwood Press.

Hair, J.F. Jr., W.C. Black, B.J. Babin, and R.E. Anderson. 2010. Multivariate Data Analysis. Upper Saddle River, NJ: Prentice Hall.

Harwood, J., R. Heifner, K. Coble, J. Perry, and A. Somwaru. 1999. Managing Risk in Farming: Concepts, Research, and Analysis. Agricultural Economic Report No. 774. Washington, DC: Market and Trade Economics Division and Resource Economics Division, USDA Economic Research Service.

Hatfield, J., G. Takle., R. Grotjahn., P. Holden., R.C. Izaurralde., T. Mader, and E. Marshall. 2014. Climate Change Impacts in the United States: The Third National Climate Assessment Congress, US Global Change Research Program, 150-174.

Hruschka, D.J., D. Schwartz, D.C. St John, E. PiconeDecaro, R.A. Jenkins, and J.W. Carey. 2004. Reliability in coding open-ended data: Lessons learned from HIV behavioral research. Field Methods 16(3):307-331.

IDALS (Iowa Department of Agriculture and Land Stewardship), IDNR (Iowa Department of Natural Resources) and ISU (Iowa State University). 2014. Iowa Nutrient Reduction Strategy, Ames, IA. http:// www.nutrientstrategy.iastate.edu/.

ISUEO (Iowa State University Extension and Outreach). 2014. Reducing Nutrient Loss: Science Shows What Works. Ames, IA: Iowa State University Extension and Outreach.

Kaspar, T.C., D.B. Jaynes, T.B. Parkin, T.B. Moorman, and J.W. Singer. 2012. Effectiveness of oat and rye cover crops in reducing nitrate losses in drainage water. Agricultural Water Management 110:25-33.

Kaspar, T.C., J.K. Radke, and J.M. Laflen. 2001. Small grain cover crops and wheel traffic effects on infiltration, runoff, and erosion. Journal of Soil and Water Conservation 56(2):160-64.

Kaspar,T.C., and J.W. Singer. 2011. The use of cover crops to manage soil. In Soil Management: Building a Stable Base for Agriculture, eds. J.L. Hatfield and T.J. Sauer, 321-337. 
Madison, WI: American Society of Agronomy and Soil Science Society of America.

Kladivko, E.J., J.R. Frankenberger, D.B. Jaynes, D.W. Meek, B.J. Jenkinson, and N.R. Fausey. 2004. Nitrate leaching to subsurface drains as affected by drain spacing and changes in crop production system. Journal of Environmental Quality 33:1803-13.

Kladivko, E.J., T.C. Kaspar, D.B. Jaynes, R.W. Malone, J. Singer, X.K. Morin, and T. Searchinger. 2014 Cover crops in the upper Midwestern United States: Potential adoption and reduction of nitrate leaching in the Mississippi River Basin. Journal of Soil and Water Conservation 69(4):279-291, doi:10.2489/ jswc.69.4.279.

Knowler, D., and B. Bradshaw. 2007. Farmers' adoption of conservation agriculture: A review and synthesis of recent research. Food Policy 32:25-48.

Kremen, C., and A. Miles. 2012. Ecosystem services in biologically diversified versus conventional farming systems: Benefits, externalities, and trade-offs. Ecology and Society 17(4):40-65.

Lal, R., J.A. Delgado, P.M. Groffman, N. Millar, C. Dell, and A. Rotz. 2011. Management to mitigate and adapt to climate change. Journal of Soil and Water Conservation 66(4):276-285, doi:10.2489/jswc.66.4.276.

Lemos, M.C., Y-J. Lo, C. Kirchhoff, and T. Haigh. 2014 Crop advisors as climate information brokers: Building the capacity of US farmers to adapt to climate change. Climate Risk Management 4-5:32-42.

Lin, B.B. 2011. Resilience in agriculture through crop diversification: Adaptive management for environmental change. Bioscience 61(3):183-93.

Lockeretz, W. 1990. What have we learned about who conserves soil? Journal of Soil and Water Conservation 45(5):517-523.

MCCC (Midwest Cover Crops Council). 2014. Midwest Cover Crops Council Homepage. http://www.mccc.msu.edu/.

McIver, J.P., and E.G. Carmines. 1981. Unidimensional scaling. Thousand Oaks, CA: Sage.

Morton, L.W. 2014. The science of variable climate and agroecosystem management. Journal of Soil and Water Conservation 69(6):207A-212A, doi:10.2489/ jswc.69.6.207A.

NTF (Mississippi River Gulf of Mexico Watershed Nutrient Task Force). 2013. Looking Forward:The Strategy of the Federal Members of the Hypoxia Task Force. Washington, DC: US Environmental Protection Agency.

NWF (National Wildlife Federation). 2012. Roadmap to Increased Cover Crop Adoption. Merrifield, VA: National Wildlife Federation.

Prokopy, L. 2011. Agricultural human dimensions research: The role of qualitative research methods. Journal of Soil and Water Conservation 66(1):9A-12A, doi:10.2489/ jswc.66.1.9A.

Prokopy, L.S., K. Floress, D. Klotthor-Weinkauf, and A. Baumgart-Getz. 2008. Determinants of agricultural best management practice adoption: Evidence from the literature. Journal of Soil and Water Conservation 63:300-311.

Prokopy, L.S., T. Haigh, A.S. Mase, J. Angel, C. Hart, C. Knutson, M.C. Lemos, Y.-J Lo, J. McGuire, and L.W. Morton. 2013. Agricultural advisors: A receptive audience for weather and climate information? Weather, Climate, and Society 5(2).

Prokopy, L.S., N. Mullendore, K. Brasier, and K. Floress. 2014. A typology of catalyst events for collaborative watershed management in the United States. Society and Natural Resources 27:1177-1191.

Reimer, A.P., D.K. Weinkauf, and L.S. Prokopy. 2012. The influence of perceptions of practice characteristics: An examination of agricultural best management practice adoption in two Indiana watersheds. Journal of Rural Studies 28:118-128.

Ribaudo, M. 2011. Reducing agriculture's nitrogen footprint: Are new policy approaches needed? Amber Waves 9:34-39.

Rogers, E.M. 2003. Diffusion of Innovations, 5th ed. New York, NY: The Free Press a Division of Macmillan, Inc.

Schnepf, M., and C. Cox, eds. 2006. Environmental Benefits of Conservation on Cropland: The Status of Our Knowledge. Ankeny, Iowa: Soil and Water Conservation Society.

Singer, J.W., S.M. Nusser, and C.J. Alf. 2007. Are cover crops being used in the US Corn Belt? Journal of Soil and Water Conservation 62:353-358.

Small, M.L. 2011. How to conduct a mixed methods study: Recent trends in a rapidly growing literature. Annual Review of Sociology 37:57-86

Soule, M.J., A. Tegene, and K.D. Wiebe. 2000. Land tenure and the adoption of conservation practices. American Journal of Agricultural Economics 82:993-1005.

Spector, P.E. 1992. Summated rating scale construction: An introduction. Newbury Park, CA: Sage.

Strock, J.S., P.M. Porter, and M.P. Russelle. 2004. Cover cropping to reduce nitrate loss through subsurface drainage in the northern US Corn Belt. Journal of Environmental Quality 33:1010-16.

USDA NASS (USDA National Agricultural Statistics Service). 2014. 2012 Census of Agriculture. Washington, DC: USDA National Agricultural Statistics Service.

Walthall, C.L., J. Hatfield, P. Backlund, L. Lengnick, E. Marshall, M.Walsh, S. Adkins, M.Aillery, E.A.Ainsworth, C. Ammann, C.J. Anderson, I. Bartomeus, L.H. Baumgard, F. Booker, B. Bradley, D.M. Blumenthal, J. Bunce, K. Burkey, S.M. Dabney, J.A. Delgado, J. Dukes, A. Funk, K. Garrett, M. Glenn, D.A. Grantz, D. Goodrich, S. Hu, R.C. Izaurralde, R.A.C. Jones, S-H. Kim, A.D.B. Leaky, K. Lewers, T.L. Mader, A. McClung, J. Morgan, D.J. Muth, M. Nearing, D.M. Oosterhuis, D. Ort, C. Parmesan, W.T. Pettigrew, W. Polley, R. Rader, C. Rice, M. Rivington, E. Rosskopf, W.A. Salas, L.E. Sollenberger, R. Srygley, C. Stöckle, E.S. Takle, D. Timlin, J.W. White, R. Winfree, L. Wright-Morton and L.H. Ziska. 2012. Climate Change and Agriculture in the United States:
Effects and Adaptation. Congress: 186. http://www.usda. gov/oce/climate_change/effects_2012/CC\%20and $\% 20$ Agriculture\%20Report\%20\%2802-04-2013\%29b.pdf. 